IZA DP No. 4312

Immigrant Circulation and Citizenship:

Hotel Canada?

Don J. DeVoretz

July 2009 


\title{
Immigrant Circulation and Citizenship: Hotel Canada?
}

\author{
Don J. DeVoretz \\ Simon Fraser University \\ and IZA
}

Discussion Paper No. 4312

July 2009

\author{
IZA \\ P.O. Box 7240 \\ 53072 Bonn \\ Germany \\ Phone: +49-228-3894-0 \\ Fax: +49-228-3894-180 \\ E-mail: iza@iza.org
}

Any opinions expressed here are those of the author(s) and not those of IZA. Research published in this series may include views on policy, but the institute itself takes no institutional policy positions.

The Institute for the Study of Labor (IZA) in Bonn is a local and virtual international research center and a place of communication between science, politics and business. IZA is an independent nonprofit organization supported by Deutsche Post Foundation. The center is associated with the University of Bonn and offers a stimulating research environment through its international network, workshops and conferences, data service, project support, research visits and doctoral program. IZA engages in (i) original and internationally competitive research in all fields of labor economics, (ii) development of policy concepts, and (iii) dissemination of research results and concepts to the interested public.

IZA Discussion Papers often represent preliminary work and are circulated to encourage discussion. Citation of such a paper should account for its provisional character. A revised version may be available directly from the author. 
IZA Discussion Paper No. 4312

July 2009

\section{ABSTRACT \\ Immigrant Circulation and Citizenship: Hotel Canada?}

Canada has experienced a unique problem as a subset of its immigrants, approximately $10 \%$, leave after ascension to citizenship. In this paper I argue that both the degree of immigrant naturalization and subsequent emigration from Canada is conditioned by economic opportunities and Canadian citizenship policies. A triangular model of movement comprising the concept of an entrepôt destination serves as a basis to argue that immigrants to entrepôt countries are faced with the decision to stay or leave after citizenship ascension. Limited evidence is presented to support the conclusion that recently naturalized Canadian immigrants who leave for a third country (USA) or return home (Hong Kong) experience positive selection and overachieve.

JEL Classification: J62

Keywords: emigration, return migration, citizenship

Corresponding author:

Don J. DeVoretz

Simon Fraser University

Burnaby, B.C.

Canada V5A 156

E-mail: devoretz@sfu.ca 


\title{
Immigrant Circulation and Citizenship: Hotel Canada?
}

\author{
Don J. DeVoretz ${ }^{1}$ \\ "You can check out anytime you like, but you can never leave" \\ Lyrics from Hotel California by Don Henley and Glenn Fry
}

\section{Introduction}

Immigrant ascension to citizenship has often been viewed as a paramount step in the immigrant integration process. The modern immigrant-receiving nation state recognizes this fact by often placing stringent criteria on the immigrant citizenship ascension process. In this paper I argue that immigrants' ascension to citizenship is one step in a series of decisions on mobility which ironically may induce newly naturalized citizens to leave the host country.

The economic consequences of this move affect the three agents involved in the migration process: the host state, the sending state, and the migrant. It is the purpose of this paper to provide a model to predict the likelihood of recently naturalized citizens to stay or leave and to describe the economic consequences of their decision on the three agents. The latter of course have dramatically different viewpoints on post-naturalization emigration (DeVoretz 2006). Newly naturalized citizens can see further emigration as a mechanism to increase their economic welfare, while policymakers in the host country may interpret post-naturalization emigration as a loss of heavily subsidized human capital which in turn creates an impending long-term economic liability. In short, policymakers and citizens alike may come to feel that Canada plays the role of a hotel to short-term guests. Finally, the sending country may induce return migration to capture the human capital embodied in émigrés along with associated networking gains.

\section{Triangular Movement}

The argument embedded in Figure 1 is that citizenship ascension occurs after immigrants migrate from the sender country (A) to the entrepôt country (B). This entrepôt country is defined as an immigrant-receiving area that provides extensive subsidized human capital to recently arrived immigrants. Thus, the decision to ascend to citizenship is embedded in a geographical space since it is made after time is spent in the entrepôt country (B). This citizenship acquisition decision has further geographical implications since a new passport can facilitate further movement to (C) or the rest of the world (ROW). However, citizenship ascension can in turn reduce the probability of returning to the sender country (A) if dual citizenship is not recognized by either country.

\footnotetext{
${ }^{1}$ Don DeVoretz is a professor at Simon Fraser University and he can be contacted at devoretz@sfu.ca
} 


\section{Figure 1: Immigrant Triangle}

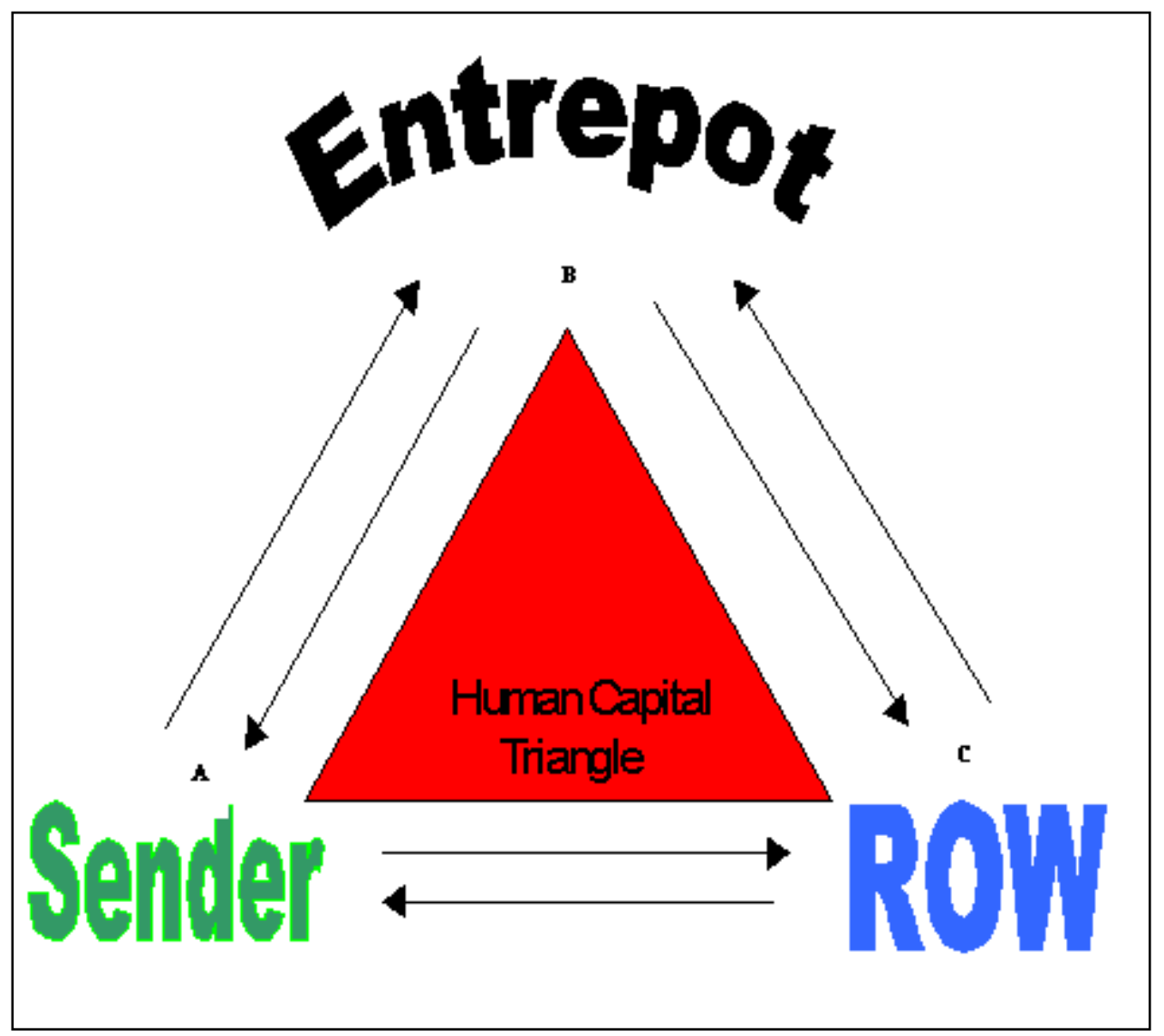

Moreover, while immigrants reside in the entrepôt country, forces appear to condition their decision to naturalize. ${ }^{i}$ In particular, risk-adverse immigrants who want to invest in themselves leave country (A) as they are concerned with accumulating human capital. In this triangular model the entrepôt destination differentiates itself from the ROW by the presence of private and public agents who provide subsidized human capital and free public goods (DeVoretz and Ma 2002). The subsidized provision of human capital includes language training, retraining for certification of credentials, extended welfare benefits and anticipated future social security benefits as well as subsidized formal education. Moreover, with little or no waiting period, the entrepôt country provides three public goods to immigrants: family reunification privileges, citizenship, and a passport and near visa-free travel.

On the other hand, the ROW is defined as a set of countries (e.g., the United States) where immigrants receive no subsidized human capital and must wait a long time to obtain public goods, and hence this environment attracts risk-taking immigrants. ${ }^{\text {ii }}$

Given the provision of subsidized human capital benefits, it is argued by DeVoretz and Ma (2002) that risk-averse immigrants will rationally choose the entrepôt destination or the ROW, 
and then refrain from, or ascend to, citizenship. However, ascension to citizenship in an entrepôt destination will only occur if, at a later stage, a secondary calculation reveals that the costs of ascending to citizenship are lower than the benefits.

What are the costs of ascension to citizenship? The major cost arises in the absence of mutually recognized dual citizenship policy by both the sending and receiving countries, since under these conditions citizenship in the entrepôt country reduces or eliminates future access to the sending country's labour market. The economic benefits to citizenship ascension are argued to include greater access to both the entrepôt's labour market and all labour markets accessible by the immigrant via the newly acquired passport from the entrepôt country.

Several major predictions now appear under this triangular model which combines a geographical time-space dimension and an embedded utility-maximizing component to predict citizenship ascension. These include immigrant self-selection: risk-averse immigrants choose country B and risk takers move directly to country C. In addition, once in entrepôt country B, those immigrants who enjoy mutual dual citizenship recognition and have, while in residence, accumulated substantial subsidized human capital, will likely acquire citizenship. Moreover, given the increase in their human capital and the anticipated access to a wider labour market post-naturalization, those immigrants who become citizens will have higher incomes.

In sum, this triangular model predicts that risk-adverse immigrants will choose the entrepôt country and that some of them will selectively ascend to citizenship and reaps economic rewards from naturalization.

\section{Immigrant Decision Tree}

Figure 2 allows us to better understand the individual migrant's choice to stay or to move at each point in the triangle (countries A, B and C) and the role of the state in influencing that choice. At the outset I assume that our potential migrant in country A is myopic and will thus face a binary choice at each location, as depicted in Figure 2.

\section{Stage I}

In Stage 1 the migrants can either choose to obtain a job, further their education or migrate to an entrepôt country (B) to obtain further education and/or gain subsidized general human capital, such as language skills, and a job. ${ }^{\text {iii }}$ An alternative migration-education strategy faced by the migrant in country A is to immediately leave country A to obtain an education in the entrepôt country in Period I. ${ }^{\text {iv }}$

I argue that the majority of the migrants who leave country A will attempt to enter an entrepôt country (B) where two agents will confer added benefits on them. ${ }^{\mathrm{v}}$ The first quasi-private agent in the entrepôt country (B) represents a publicly subsidized institution (university, nongovernment organization) that confers subsidized benefits on successful student applicants in Period I of Stage II. The second agent is the settlement worker who, by definition, provides limited general human capital (e.g., basic language training, adjustment to cultural mores, basic 
job search techniques) to enhance integration. Settlement workers may also have altruistic motives, namely to ease the immigrant's integration into society. ${ }^{\mathrm{vi}}$

\section{Figure 2: A Four-Stage Nested Stayer-Mover Model}

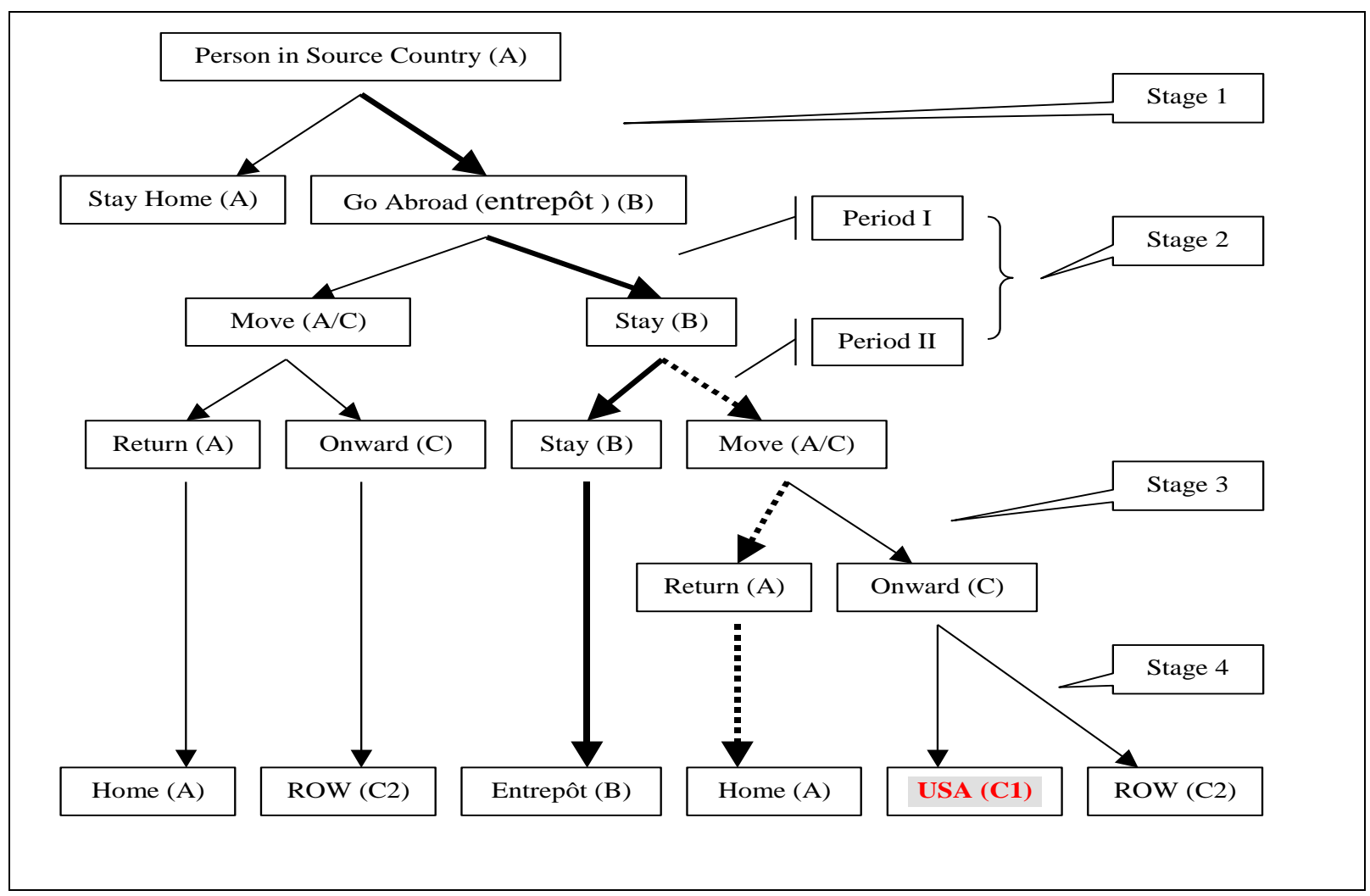

\section{Period I of Stage 2}

The second type of benefits conferred on migrants in the entrepôt country during Period I of Stage 2 are advanced forms of general human capital (enhanced language training, certification of past degrees, credential recognition, bridge training, etc.) more or less portable across economies. ${ }^{\text {vii }}$ Why would an entrepôt country subsidize the acquisition of such human capital? Ironically the rationale most often cited in the entrepôt country is to induce migrants to stay at the end of Period I and repay (via taxes) their subsidized education. However, when outside regimes (e.g., home or ROW) offer a greater reward for the migrants' subsidized capital, the probability of migrants leaving at the end of Period II increases. ${ }^{\text {viii }}$ They can either move at the end of Period I in Stage 2 and return home (A) or favour a limited number of onward destinations (only $\mathrm{C} 2$ countries). ${ }^{\text {ix }}$

\section{Period II of Stage 2}

Once our prototypical immigrant has acquired subsidized specific and general human capital and decides to stay in B at the end of Period I in Stage 2, several legal institutions and state instruments intervene to affect the decision to leave or to stay at the end of Period II in Stage 2. 
The first set of these state instruments stem from the country of origin (A). The government in the sending country (A) may define the terms and conditions of return migration.

Let us review two extreme cases of the terms and conditions embedded in country A's stylized passports which affect the potential returning migrant's decision to stay in country (B) or leave for home (A) at the end of Period II of Stage 2. First, under passport P1, the sending country requires that the immigrant return at the end of Period II in country (B), or forfeit a previously posted bond. Under passport P2 the sending country alternatively allows an indefinite extension of the migrant's stay in the entrepôt (B) or other countries (United States, ROW) without penalty or sanction. Thus, the sending country (A) can either encourage or discourage the decision to stay in the entrepôt country (B) at the end of Period II of Stage 2 depending upon the type of passport issued in Stage I.

At the end of Period II of Stage 2, a public agent may either compel or encourage the ascension to citizenship of the immigrant who remained in the entrepôt country (B). In the extreme case, the immigrant may be compelled to exercise the right of ascension to citizenship or leave the entrepôt country. I n other words, the ascension to citizenship constitutes an "up or out" decision at the end of Period II in Stage 2 depending on whether or not citizenship is granted. ${ }^{\mathrm{x}}$ If it is rejected, migrants must leave for their home (A) or move onto another country (C2 or ROW). ${ }^{\mathrm{xi}}$

If migrants successfully ascend to citizenship in the entrepôt country, the sending country may prohibit them from returning and working in their country of origin (A) by denying them dual citizenship. ${ }^{\text {xii }}$ Thus, ascending to citizenship in the entrepôt country (B) can block a return move to country A, or allow a move to $\mathrm{C} 1$ (United States), and increase the probability of a move to $\mathrm{C} 2$. These various outcomes are by products of the public good aspects of both citizenship and the resulting passport issued by country B. As noted earlier, return movement to country A after ascending to citizenship in B is blocked by the lack of recognition in country A of dual citizenship. However, country B's citizenship allows free access to any free mobility zone covered under various trade treaties (e.g., NAFTA for Canada) of which country B is a signatory. In this case, the new immigrant free rides on the inherent public good of citizenship in B which is recognized by country $\mathrm{C} 1$ (United States) through prior negotiation with citizens of country B. ${ }^{\text {iii }}$ I also argue that benefits of the past good actions of country B's past passport holders will confer mobility benefits on new passport holders in country B. For example, new passport holders in the entrepôt country now will be allowed entrance to a larger set of countries in C2 without the requirement of a visitor's visa or waiting in long queues to obtain a working visa. ${ }^{\text {xiv }}$

In sum, we have outlined the complexity of the choices faced by migrant residents of countries (A) or (B). In fact, Figure 2 outlines seven possible strategies from (A-A-A) to (A-B-C2), and only under a few set of conditions will a dominant strategy appear unless we know the socioeconomic conditions of immigrants and the particular political institutions and regulations in each country. In the next section, I will outline the most common strategies employed under Figure 2 by Canadian immigrants circa 2001 through reference to two case studies conducted within the framework of the triangular model. 


\section{Economic and Mobility Impacts of Naturalization}

\section{Economic Impacts}

I argue at this point that the key institutional change that occurs in the immigrant path outlined in Figure 2 is the decision to ascend to citizenship. If an immigrant chooses to ascend to citizenship (and not all do) the substantial economic gains depicted in Figures 3 and 4 should lead the migrant to stay in country B.

Figure 3 reveals actual sizable citizenship effects for both the Chinese and the British earnings functions in Canada. However, the citizenship effect on Chinese earnings is larger. A Canadianborn age earnings profile is reported as a reference point (CB), and further highlights the citizenship effect on earnings. As noted, a Chinese immigrant experiences a substantial earnings disadvantage upon arrival, but ascension to citizenship results in increased earnings such as to nearly equal that of the Canadian-born. The observed citizenship effect on British immigrant earnings is smaller but sufficient to make these immigrants "overachievers". In other words, without citizenship British immigrants do not suffer an initial earnings disadvantage relative to the Canadian-born. However, after obtaining citizenship, British immigrants become "overachievers" and earn more than the Canadian-born.

Figure 3. Age-earnings profiles for the Canadian Groups

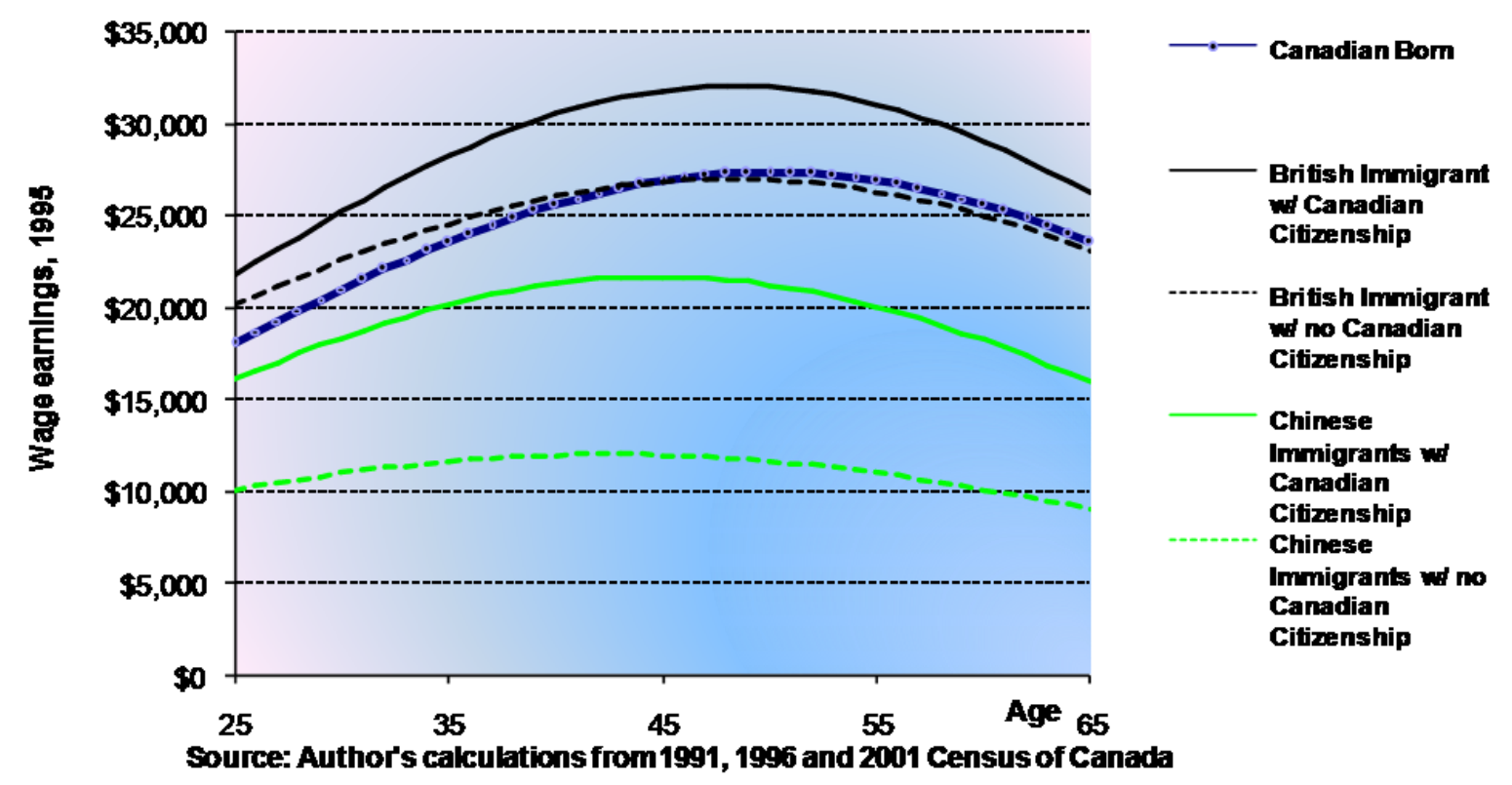

As shown in Figure 4 the economic impacts of citizenship on migrants from the United States and India were also favourable, with naturalized Indians deriving a larger reward from citizenship than the Chinese. 
Figure 4: Age-eamings profiles for the Canadian groups

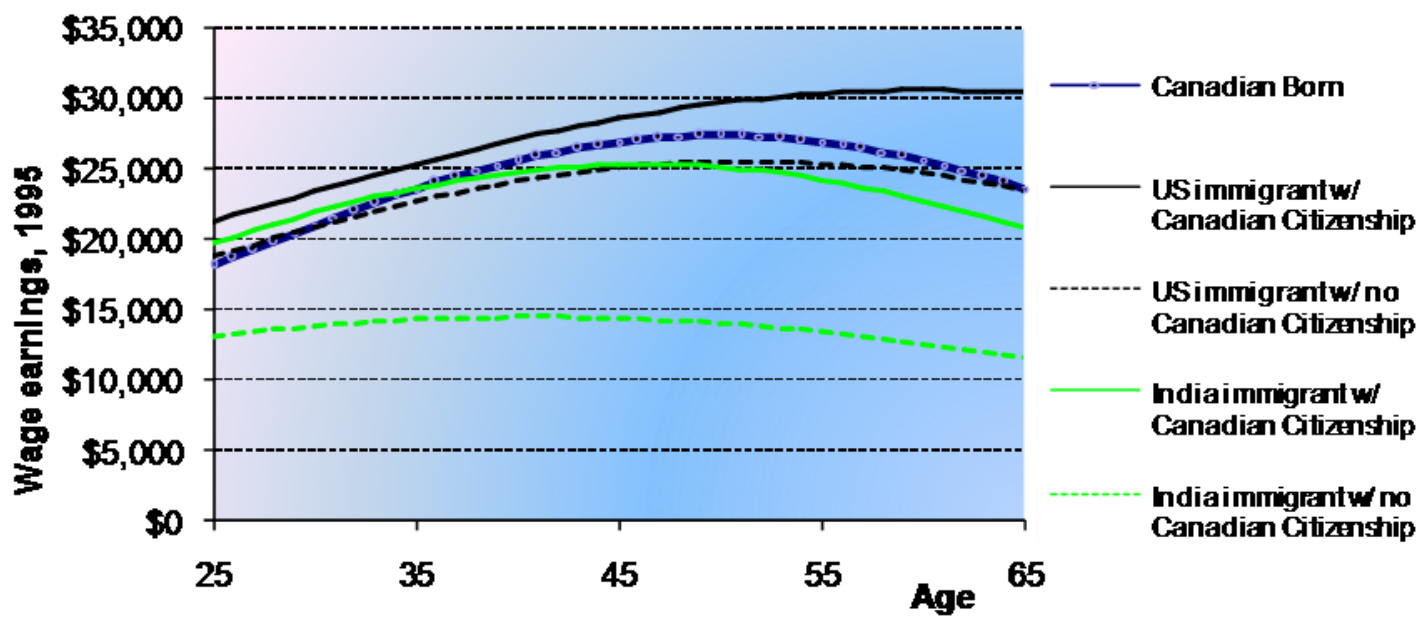

Source: Authors' calculations from 1996. 1996 and 2001 Census of Canada

\section{Naturalization and Mobility Impacts}

The sizable economic gains from citizenship ascension shown in Figures 3 and 4 are replicated in many countries as reported by Bevelander and DeVoretz (2008). However, there may still be economic incentives for newly naturalized citizens to move on to the ROW, return home (country A), or stay in country B, as depicted in Figure 2. Migrants may now choose a path to maximize their income stream net of costs given the citizenship effect, their human capital stock before and after moving, and the transactions costs of movement.

Some examples should illustrate this choice. Suppose a newly naturalized immigrant is an economic overachiever in country B (Figures 3 and 4, naturalized British) and both countries A and $\mathrm{B}$ jointly recognize dual citizenship, then the newly naturalized citizen will remain in $\mathrm{B} .{ }^{\mathrm{xv}}$ However, if the economic premium derived from citizenship does not produce a 'catch-up or cross-over' point for the naturalized immigrants (Figures 3 and 4, naturalized Chinese), then the immigrants may return home (country A) or move on to the ROW depending on the changing transaction costs associated with their new citizenship. If dual citizenship is not recognized by country A, then the newly naturalized citizens in country B will not return home. Their choice now becomes to stay in country B or move on to the ROW. Immigrants will leave country B if the economic prospects in the ROW are at least equal to those in country B and if their new passport lowers the transactions costs of movement to the ROW. In the real world this is exactly the case of Chinese naturalized Canadian citizens with respect to further movement to the United States. ${ }^{\text {xvi }} \mathrm{A}$ third empirically relevant case is characterized by recently naturalized Ukrainians in North America. Given the confluence of a continuing faltering Ukrainian economy, Ukraine's 
lack of recognition of dual citizenship and the 'overachiever' status of recently naturalized Ukrainians in North America little return or ongoing migration should be observed by naturalized Ukrainians in North America. ${ }^{\text {xvii }}$

\section{Some Empirical Evidence}

\section{Citizenship Ascension}

The key prediction of this economic model of citizenship acquisition is that only if the net benefits of naturalization are positive will the immigrant ascend to citizenship. In turn if the economic benefits derived from citizenship acquisition are larger in the sending country or the ROW, the newly naturalized immigrant will leave and create the conditions of entrepôt or hotel status for the host country. Otherwise the naturalized immigrant will stay.

The differential rates of immigrant naturalization in Canada reported in Figure 5 support the empirical findings presented in Figures 3 and 4 on the economic gains associated with citizenship acquisition.

Figure 5: Proportion of naturalized citizens among immigrants from high income countries (USA, Germany, Italy, Netherlands) and low income countries (China and India)

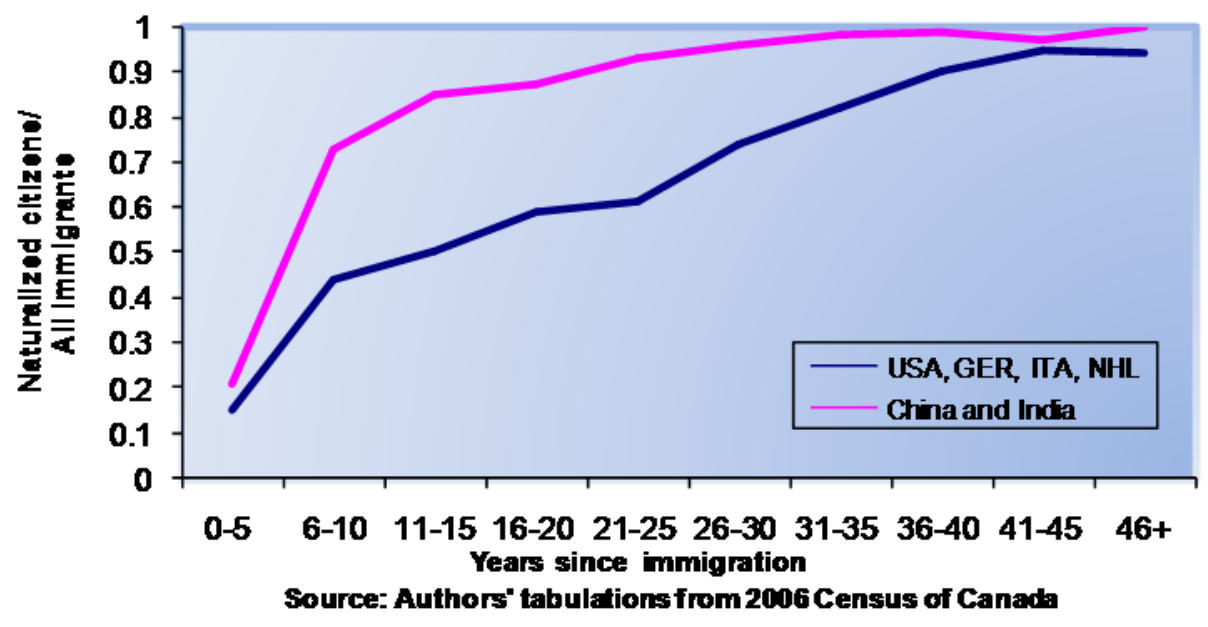

The older vintage of European and United States immigrants experience a mild spurt in citizenship acquisition in the first five years of eligibility, from $10 \%$ to $40 \%$, but do not approach the Chinese or Indian rates of citizenship acquisition until after 45 years of residence in Canada.

Why is there such a gap in citizenship acquisition across countries of origin and vintages of immigrants? Several forces appear in my model to affect the probability of citizenship acquisition across these vintages. However, where the economic benefits of citizenship acquisition are as large as those reported for China and India in Figures 3 and 4) the acquisition will be quick and robust, as shown in Figure 5. 
Additional differential benefits accrue to the Chinese and Indian nationals who acquire citizenship. These groups can now enter the United States labour market with a TN or NAFTA visa available only to Canadian citizens. Of course, United States and Western European immigrants to Canada already hold passports which allow entry to their holders into NAFTA or EU labour markets respectively. This reduces their incentive to naturalize as illustrated in Figure

\section{Citizenship Ascension and Mobility}

The empirical data shown in Table 1 documents which newly naturalized citizens will stay in Canada to create a permanent home and who will leave Hotel Canada. Table 1 reports the number of resident naturalized immigrants by country of origin over time corrected for survival rates and correcting for the 2006 census weights. In short I calculate the forward census survival group predicted by the number of residents in the previous census. If the actual number in the future census is smaller, outmigration has occurred. For example, the absolute outmigration for Hong Kong immigrants to Canada between 1996 and 2000 is 30,140, or the difference between the $1996(165,450)$ and the 2000 resident Hong Kong population $(135,310) .{ }^{\text {xviii }}$

Table 1 reports that for immigrants who arrived between 1960 and 1996 a select group from mainly Hong Kong, Taiwan, the United States, and Yugoslavia moved out at the respective rates of $18.2 \%$ (8.3\%), 25\% (14\%) 9\% (2\%) 22.7\% (39\%) over the period 1996-2000 (2001-2005). These are impressive rates for such short intervals.

Table 1: Older Vintage Canadian Immigrants: Age in 1996: 21 to 55; Landing Year 1960 to 1996

\begin{tabular}{|c|c|c|c|c|c|c|c|}
\hline $\begin{array}{l}\text { Selected } \\
\text { Country }\end{array}$ & $\begin{array}{l}1996 \text { weighted } \\
\text { rounded }\end{array}$ & $\begin{array}{c}1996 \text { weighted } \\
\text { rounded 5-year } \\
\text { survival }\end{array}$ & $\begin{array}{l}1996 \text { weighted } \\
10 \text {-ye survival }\end{array}$ & $\begin{array}{l}2001 \text { weighted } \\
\text { rounded }\end{array}$ & $\begin{array}{l}2006 \text { weighted } \\
\text { rounded }\end{array}$ & $\begin{array}{c}\text { Out- } \\
\text { migration } \\
96-00\end{array}$ & $\begin{array}{c}\text { Out- } \\
\text { Migration } \\
01-05\end{array}$ \\
\hline Australia* & 9,600 & 9,520 & 9,390 & 8,740 & 8,440 & 780 & 170 \\
\hline China & 117,880 & 116,720 & 114,930 & 109,780 & 113,940 & 6,940 & $-5,950$ \\
\hline France & 36,280 & 35,940 & 35,420 & 33,270 & 32,140 & 2,670 & 610 \\
\hline Germany & 51,190 & 50,640 & 49,780 & 48,030 & 47,310 & 2,610 & -140 \\
\hline Greece & 38,710 & 38,200 & 37,420 & 36,050 & 37,690 & 2,150 & $-2,420$ \\
\hline Guyana & 56,370 & 55,910 & 55,210 & 54,880 & 54,710 & 1,030 & -530 \\
\hline Haiti & 33,450 & 33,170 & 32,740 & 31,750 & 32,160 & 1.420 & -840 \\
\hline Hong Kong & 166,690 & 165,450 & 163,570 & 135,310 & 122,150 & 30,140 & 11,280 \\
\hline Hungary & 13,160 & 13,010 & 12,780 & 11,600 & 11,650 & 1,410 & -280 \\
\hline India & 164,780 & 163,330 & 161,110 & 159,840 & 164,150 & 3,490 & $-6,530$ \\
\hline Iran & 32.470 & 32,210 & 31,820 & 27,840 & 27,160 & 4,370 & 290 \\
\hline Italy & 115,250 & 113,750 & 111,400 & 114,140 & 113,880 & -390 & $-2,090$ \\
\hline Jamaica & 80,140 & 79,460 & 78,410 & 76,660 & 74,570 & 2,800 & 290 \\
\hline Japan* & 9,690 & 9,600 & 9,450 & 8,680 & 8,300 & 920 & 230 \\
\hline Lebanon & 43,990 & 43,660 & 43,160 & 41,480 & 40,530 & 2,180 & 450 \\
\hline Netherlands & 26,260 & 25,960 & 25,500 & 25,510 & 25,720 & 450 & -670 \\
\hline New Zealand* & 5,560 & 5,510 & 5,430 & 5,190 & 5,050 & 320 & 60 \\
\hline Philippines & 132,800 & 131,740 & 130,120 & 128,990 & 128,890 & 2,750 & $-1,520$ \\
\hline
\end{tabular}




\begin{tabular}{|c|c|c|c|c|c|c|c|}
\hline Poland & 92,360 & 91,600 & 90,440 & 86,730 & 85,810 & 4,870 & -240 \\
\hline Portugal & 106,540 & 105,550 & 104,020 & 102,720 & 101,620 & 2,830 & -430 \\
\hline Singapore* & 5,260 & 5,220 & 5,160 & 4,790 & 4,540 & 430 & 190 \\
\hline South Korea & 30,150 & 29,860 & 29,420 & 27,190 & 26,120 & 26,780 & 630 \\
\hline Sri Lanka & 46,290 & 45,950 & 45,450 & 42,890 & 41,900 & 3,060 & 490 \\
\hline Taiwan & 29,460 & 29,200 & 28,800 & 21,850 & 18,400 & 7,350 & 3,050 \\
\hline $\begin{array}{c}\text { Trinidad \& } \\
\text { Tobago }\end{array}$ & 45,150 & 44,730 & 44,080 & 42,540 & 41,490 & 2,190 & 400 \\
\hline $\begin{array}{c}\text { United } \\
\text { Kingdom }\end{array}$ & 271,130 & 268,260 & 263,820 & 263,070 & 259,780 & 5,190 & $-1,150$ \\
\hline United States & 134,820 & 133,620 & 131,770 & 121,340 & 117,090 & 12,280 & 2,400 \\
\hline Vietnam & 102,890 & 102,190 & 101,160 & 103,260 & 105,690 & $-1,070$ & $-3,460$ \\
\hline Yugoslavia & 30,960 & 30,670 & 30,230 & 23,700 & 13,920 & 6,970 & 9,340 \\
\hline
\end{tabular}

*Source: Author's calculation from 1996 - 2006 Census of Canada

Outmigration rates for the vintage of immigrants who arrived between 1996 and 2000 are presented in Table 2. Over the 2000-2005 period 54.5\% of immigrants from the former Yugoslavia and $16 \%$ of Iranian immigrants left Canada. In addition, high percentages for China (6\%), Hong Kong (14.3\%), and Taiwan (20.3\%) meant that Chinese-based immigrants to Canada were leaving at a crisp pace. In sum Tables 1 and 2 illustrate the direction and size of Canada's outmigration and illustrate that both the older and newer vintages of immigrants from greater China, Iran and Yugoslavia are leaving Canada in substantial numbers, supporting the view that, for some immigrants, Canada is a hotel.

Table 2: New Immigrants: Age in 2001: 21 to 55; Landing Year 1996 to 2000

\begin{tabular}{|c|c|c|c|c|}
\hline Selected Country & 2001 weighted rounded & $\begin{array}{c}\text { 2001 weighted rounded } \\
\text { 5-yr survival }\end{array}$ & 2006 weighted rounded & Out-Migration 01-05 \\
\hline Australia* & 1,440 & 1,430 & s.p. & 180 \\
\hline China & 76,610 & 76,090 & 71,850 & 4,240 \\
\hline France & 9,000 & 8,950 & 7,140 & 1,810 \\
\hline Germany & 3,930 & 3,900 & 4,080 & -180 \\
\hline Greece & s.p. & s.p. & 4,860 & 70 \\
\hline Guyana & 4,960 & 4,930 & 3,860 & -350 \\
\hline Haiti & 3,530 & 3,510 & 19,580 & 3,290 \\
\hline Hong Kong & 23,070 & 22,870 & 1,360 & 20 \\
\hline Hungary & 1,380 & 1,380 & 63,160 & $-6,050$ \\
\hline India & 57,510 & 57,110 & 15,550 & 2,960 \\
\hline Iran & 18,660 & 18,510 & s.p. & 110 \\
\hline Italy & 1,370 & 1,360 & 6,260 & -130 \\
\hline Jamaica & 6,170 & 6,130 & 3,110 & 480 \\
\hline Japan* & 3,610 & 3,590 & 4,650 & 210 \\
\hline Lebanon & 4,890 & 4,860 & 1,880 & 180 \\
\hline Netherlands & 2,070 & 2,060 & s.p. & \\
\hline New Zealand* & s.p. & s.p. & 34,740 & $-1,430$ \\
\hline Philippines & 33,530 & 33,310 & 5,210 & -10 \\
\hline Poland & 5,240 & 5,200 & 1,830 & -220 \\
\hline Portugal & 1,620 & 1,610 & s.p. & \\
\hline Singapore* & s.p. & s.p. & 13,570 & 1,160 \\
\hline South Korea & 14,850 & 14,730 & & \\
\hline
\end{tabular}




\begin{tabular}{|c|c|c|c|c|}
\hline Sri Lanka & 15,110 & 15,010 & 14,760 & 250 \\
\hline Taiwan & 17,650 & 17,490 & 13,830 & 3,660 \\
\hline Trinidad \& Tobago & 3,800 & 3,770 & 4,090 & -320 \\
\hline United Kingdom & 10,860 & 10,780 & 11,140 & -360 \\
\hline United States & 10,510 & 10,440 & 9,990 & 450 \\
\hline Vietnam & 7,190 & 7,160 & 7,680 & -520 \\
\hline Yugoslavia & 9,690 & 9,620 & 4,370 & 5,250 \\
\hline
\end{tabular}

*Source: Author's calculation from 1996 - 2006 Census of Canada

Economic Consequences of Staying or Leaving

If my theory is correct those immigrants shown to leave in Tables 1 and 2 should gain by their movement, and those who stayed should outperform the leavers. I now turn to empirical evidence to test this assertion in Canada's two main destination regions, the United States, and Hong Kong.

\section{Naturalized Canadians in the United States}

The best estimate of the number of permanent Canadian citizens living in the United States circa 2000 is $1,062,640$, i.e., approximately $40 \%$ of all Canadians abroad. Canadians citizens in the United States included 920,900 Canadian-born émigrés and 141,740 naturalized Canadian citizens. Growth in both components of the resident Canadian citizen stock in the United States is evident across the decade 1990 to 2000. The 1990 United States Census reported the presence of 865,180 Canadian-born residents, for a modest $7 \%$ growth over the decade. The remainder of the growth can be attributed to naturalized Canadian citizens. ${ }^{\text {xix }}$

My reference group to identify positive or negative sorting of foreign-born Canadian émigrés to the USA will be Canadian-born citizens living in the United States in 2000. For naturalized Canadians I chose those Chinese born in China and the Indians born in India who resided in Canada in 1995 and appeared in the 2000 U.S. Census. Educational attainment, age, and linguistic abilities are human capital attributes that indicate positive or negative sorting.

Did the Chinese- and Indo-Canadian groups enter the United States with a great deal of human capital, as positive sorting would predict? Figures 6 and 7 respectively illustrate that the clear majority of both groups characterized themselves as speaking English very well. 
Figure 6: Self Reported English Skills for Indo-Canadians Resident in US

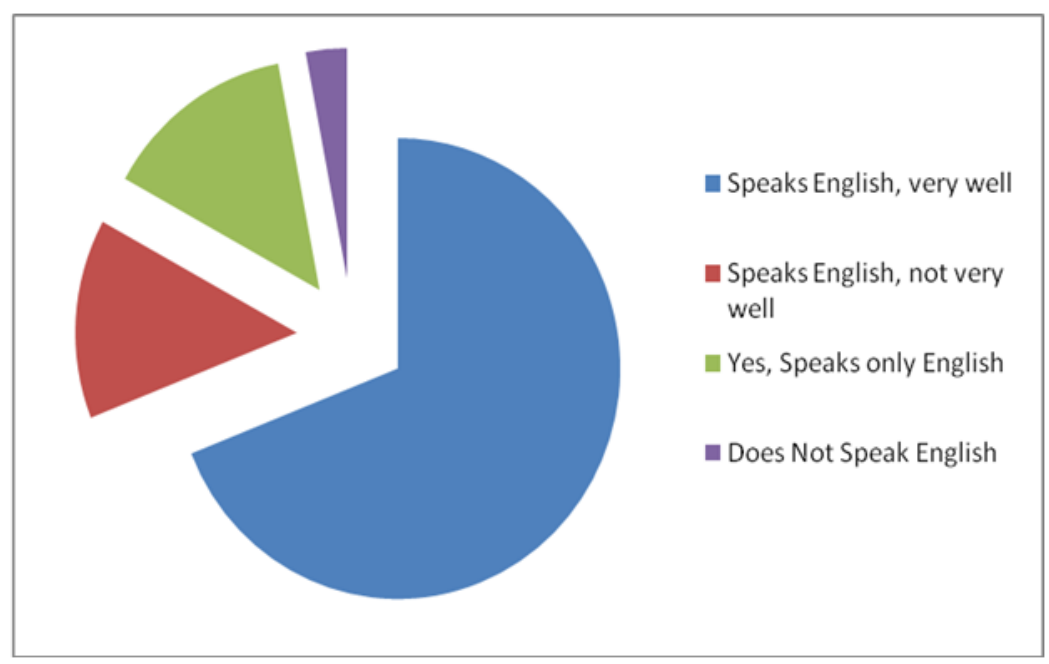

Figure 7: Self Reported English Skills for Chinese-Canadians Resident in US

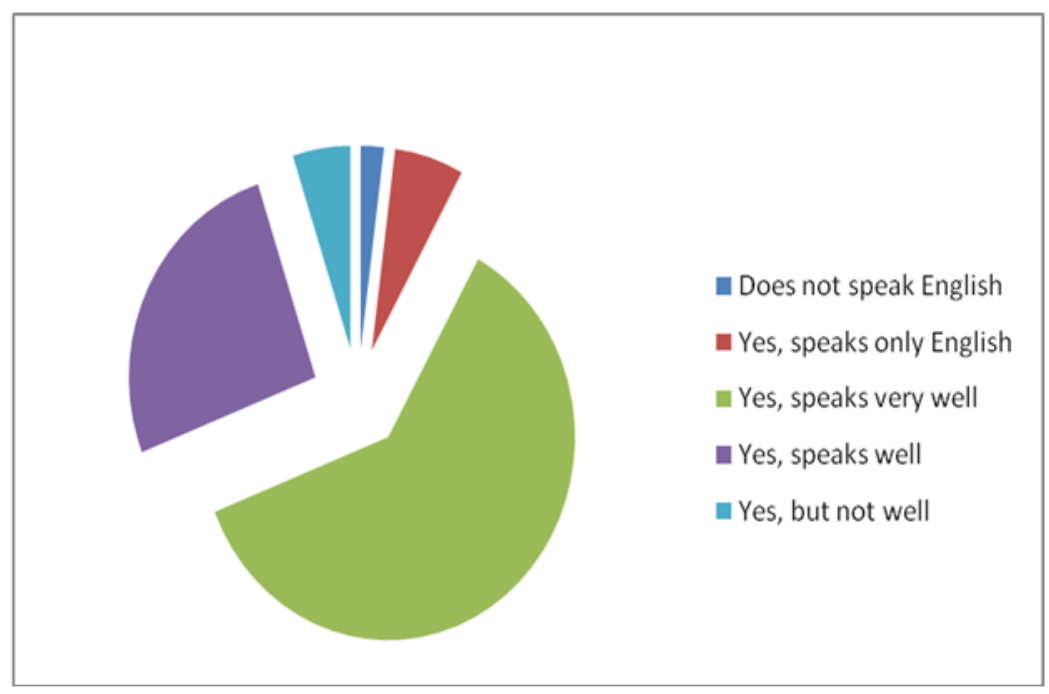

Central to our triangular argument is the outcome that both of these subgroups should obtain high educational attainments. Figures 8 and 9 clearly show that both of these subgroups are well educated since the vast majority in either group holds at least a Bachelor's degree. 

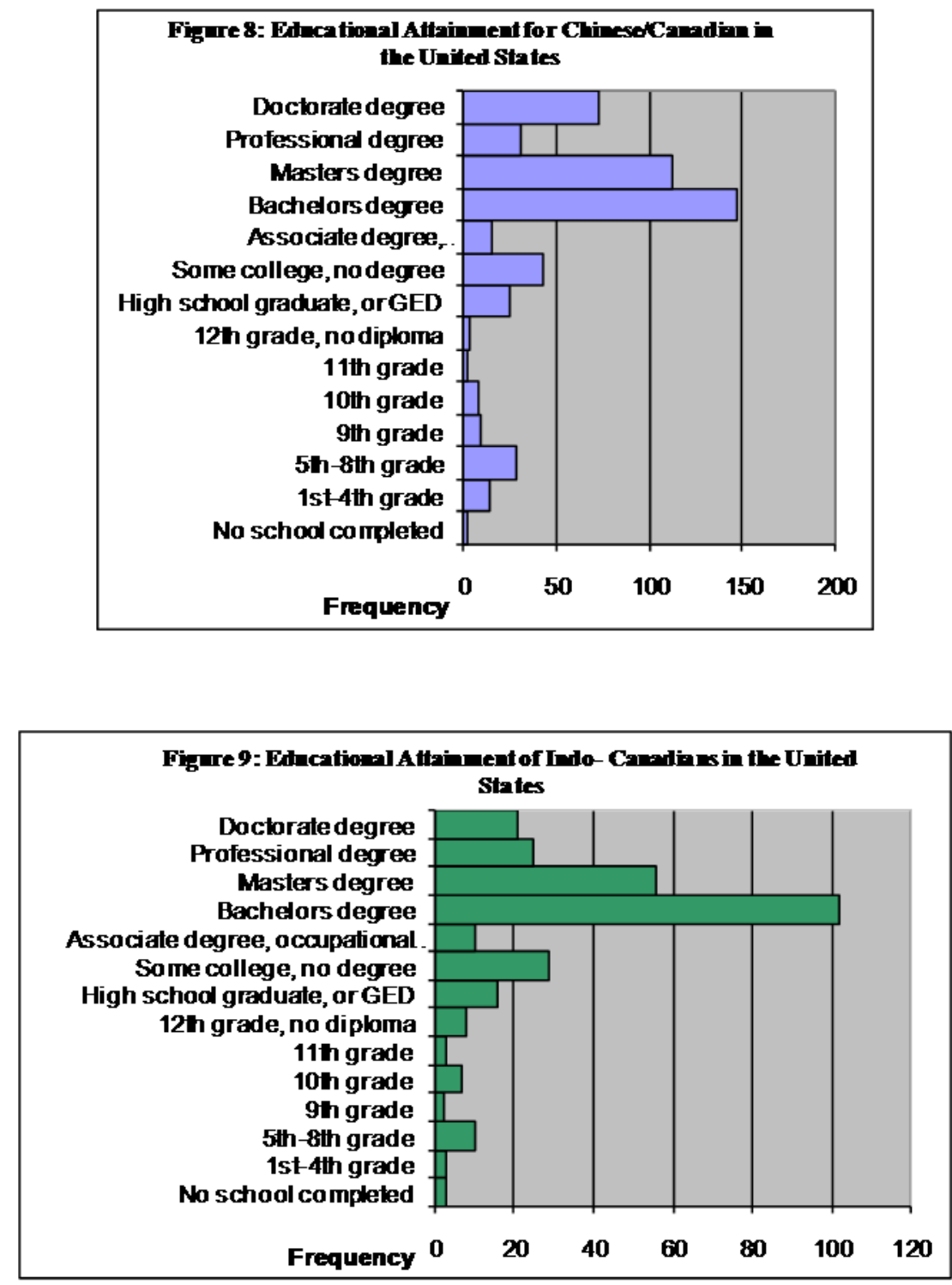

Source for Figures 6 - 9: Author's calculations US 2000 Census

In addition, more Chinese-Canadians living in the United States either held a Masters or Doctoral degree relative to Indo-Canadians. These findings illustrate the power of the United States policy instruments (H1-B and TN visas) which require high educational levels to gain entry into the United States.

Finally over $80 \%$ of the Chinese and Indo-Canadians living in the United States circa 2000 were in the economically active age group of 25-53.

Positive sorting depends on more than intensive human capital content embedded in Canada's émigrés; it also requires corresponding high rewards in the labour market. The mean and median values for the total personal income for our two sub-samples are presented in Table 3. 
Table 3: Total Personal Incomes for Chinese- and Indo-Canadians in the U.S.

\begin{tabular}{|l|l|l|l|}
\hline $\begin{array}{l}\text { TOTAL PERSONAL } \\
\text { INCOME }\end{array}$ & $\begin{array}{l}\text { Number of } \\
\text { observations }\end{array}$ & $\begin{array}{l}\text { Arithmetic mean } \\
\text { (USD) }\end{array}$ & $\begin{array}{l}\text { Median } \\
\text { (USD) }\end{array}$ \\
\hline Chinese-Canadian & 313 & $\$ 56,695$ & $\$ 50,000$ \\
\hline Indo-Canadian & 175 & $\$ 58,050$ & $\$ 43,000$ \\
\hline
\end{tabular}

Source: Author's calculations based on US 2000 Census Data excluding individuals not reporting their income and including only the employed.

The arithmetic means for the two sub-samples - US\$56,695 for Chinese-Canadians and US $\$ 58,050$ for Indo-Canadians - are high, since the average total personal income per annum for all residents in the USA is US\$36,058.

It is important to note that the Canadian-born émigré population in the United States exhibits negative sorting in terms of the percentage of individuals in the prime working years of 21-50. In fact, the mean (median) age of the Canadians born in Canada is 30.7 (29) years owing to the large number of individuals below age $21 .{ }^{\mathrm{xx}}$ Moreover, this mean age is well below the United States-born population's of 36 years.

The Chinese- and Indo-Canadians in the United States are clearly more highly educated than the Canadian-born. The proportion of residents holding a Master or a Doctoral degree is greater for the Chinese-born, $72 \%$ as opposed to $17 \%$ for the Canadian-born who appear to get a Bachelor degree in $38 \%$ of the cases.

The vast majority of the Canadian-born residents in the United States reported incomes heavily skewed to the left, of less than US\$60,000. This is strong evidence of negative sorting, although a relatively large number of Canadian-born residents in the United States making in excess of US $\$ 150,000$ raised the mean value of the earnings for the entire group.

In sum, the Chinese- and Indo-Canadians who lived in Canada in 1995 and in the United States circa 2000 are very positively sorted by the emigration process after naturalization in terms of their demographic, educational and labour-market outcomes. In fact, they have stronger economic and educational attributes than the Canadian-born in the United States. Thus, while it is clear that Canada is losing valuable human capital through positive sorting of the foreign-born, it is less clear that positive sorting holds for the Canadian-born in the United States.

\section{Naturalized Canadians in Hong Kong}

As reported in Tables 2, 3 and 4, 18\% and 14\% percent of naturalized immigrants from Hong Kong resident in Canada circa 1996-2000 and 2001-2005 left Canada, and the majority of them returned to Hong Kong. Within the triangle framework, this is a traditional move back home (A- 
B-A). In this case, the sorting between stayers in Canada and leavers to Hong Kong is more ambiguous. The traditional neo-classical literature would argue that returnees are disappointed immigrants who failed in Canada; this failure would lead to negative sorting and lower returns to Hong Kong. However, my triangle theory also suggests that they may have come to the entrepôt country (Canada) to accumulate human capital and gain a valuable Canadian passport and with the intent to exploit their social networks in China upon return to Hong Kong to raise their income. Thus, I must appeal to empirical evidence to see if the sorting was positive or negative. 
Table 4: Characteristics of Hong Kong-Born Returnees and Stayers in Canada Circa 2001

\begin{tabular}{|c|c|c|c|c|c|c|c|}
\hline \multirow[b]{3}{*}{ Total } & \multicolumn{5}{|c|}{ Returnees to Hong Kong from } & \multicolumn{2}{|c|}{$\begin{array}{r}\text { Hong Kong-Born Stayers in } \\
\text { Canada }\end{array}$} \\
\hline & \multicolumn{2}{|c|}{ All } & \multirow{2}{*}{\begin{tabular}{|c|} 
Canada \\
$33676(39.3 \%)$
\end{tabular}} & USA & Others & \multirow[b]{2}{*}{6955} & \multirow[b]{2}{*}{100.0} \\
\hline & 85793 & $100.0 \%$ & & $17778(20.7 \%)$ & $34339(40.0 \%)$ & & \\
\hline \multicolumn{8}{|l|}{ Age: } \\
\hline $0-19$ & 8236 & 9.6 & 9.4 & 4.4 & 11.1 & 1506 & 21.7 \\
\hline $20-29$ & 32430 & 37.8 & 37.5 & 39.4 & 37.6 & 1272 & 18.3 \\
\hline 30-39 & 19990 & 23.3 & 21.5 & 26.1 & 23.8 & 1745 & 25.1 \\
\hline $40-49$ & 12354 & 14.4 & 14.9 & 14.4 & 14.1 & 1630 & 23.4 \\
\hline $50-59$ & 6263 & 7.3 & 8.5 & 8 & 6.3 & 413 & 5.9 \\
\hline 60 & 6434 & 7.5 & 8.1 & 7.7 & 7.1 & 389 & 5.6 \\
\hline \multicolumn{8}{|l|}{ Sex: } \\
\hline Female & 42811 & 49.9 & 53 & 48 & 49 & 3519 & 50.6 \\
\hline Male & 42982 & 50.1 & 47 & 52 & 51 & 3436 & 49.4 \\
\hline \multicolumn{8}{|l|}{ Relation to Head of Household: } \\
\hline Head & 29170 & 34.0 & 33.5 & 35.9 & 33.9 & 1966 & 28.3 \\
\hline Spouse & 14756 & 17.2 & 18.2 & 18.0 & 16.3 & 1634 & 23.5 \\
\hline Children & 32430 & 37.8 & 38.2 & 37.1 & 37.7 & 2741 & 39.4 \\
\hline Maid & 86 & 0.1 & 0.0 & 0.0 & 0.1 & $\mathrm{n} / \mathrm{a}$ & $n / a$ \\
\hline Others & 9351 & 10.9 & 10.1 & 9.1 & 12.0 & 614 & 8.8 \\
\hline \multicolumn{8}{|l|}{ Education: } \\
\hline Primary School or less & 9180 & 10.7 & 9.2 & 6.4 & 13.1 & 392 & 6.4 \\
\hline Secondary School \& Diploma & 31314 & 36.5 & 40.3 & 23.6 & 37.5 & 4201 & 68.2 \\
\hline Local Uni. Degree & 12612 & 14.7 & 15.3 & 15.8 & 13.9 & 1571 & 25.5 \\
\hline Overseas Degree & 32687 & 38.1 & 35.2 & 54.2 & 35.5 & & \\
\hline \multicolumn{8}{|l|}{ Occupation: } \\
\hline Low Skill & 13509 & 26.7 & 25.8 & 16.9 & 30.2 & 1068 & 27.7 \\
\hline Assistant Professional & 15584 & 30.8 & 33.7 & 29.8 & 29.2 & 951 & 24.7 \\
\hline Professional & 10726 & 21.2 & 16.9 & 28.4 & 21.9 & 1038 & 26.9 \\
\hline Managerial & 10777 & 21.3 & 23.6 & 25.0 & 18.7 & 796 & 20.7 \\
\hline Total & 50596 & 100 & 100 & 100 & 100 & 3853 & 100.0 \\
\hline \multicolumn{8}{|l|}{ Earnings: } \\
\hline $1-5,999$ & 2682 & 5.3 & 5.1 & 4.4 & 5.6 & 2382 & 45.7 \\
\hline 6,000-9,999 & 5970 & 11.8 & 10.0 & 8.3 & 14.1 & 739 & 14.2 \\
\hline $10,000-14,999$ & 12345 & 24.4 & 26.7 & 17.6 & 24.7 & 753 & 14.5 \\
\hline $15,000-19,999$ & 7994 & 15.8 & 17.0 & 17.6 & 14.7 & 552 & 10.6 \\
\hline $20,000-29,999$ & 8348 & 16.5 & 18.3 & 17.5 & 14.8 & 525 & 10.1 \\
\hline$>=30,000$ & 13256 & 26.2 & 22.8 & 34.6 & 26.0 & 256 & 4.9 \\
\hline Total & 50596 & 100.0 & 100.0 & 100.0 & 100.0 & 5207 & 100.0 \\
\hline Median (HK Dollar/month) & & 16520.38 & 16500.00 & 20000.00 & 15500.00 & & 7091.03 \\
\hline Mean (HK Dollar/month) & & 25543.01 & 23314.00 & 33682.00 & 24657.00 & & 10234.78 \\
\hline Gini Coefficient** & & .11. & .13 & .55 & .15 & & .34 \\
\hline
\end{tabular}

Source: 2001 census data, Department of Census and Statistics, Hong Kong SAR, PRC and 2000 Canadian census public use individual Microdata file, http://datacentre.chass.utoronto.ca/census/mainmicro.html. 
Notes:

*For earnings, sample selected: aged 15 and over; income > 0; adjusted to 2000 real CND dollar value; exchange rate as on Dec. 31,2000 at CND\$1 = HK\$5.20777.

** Authors' calculation.

Table 4 provides a partial answer as to whether Chinese returnees to Hong Kong circa 2001 were positively selected. These returnees were highly concentrated in either the "head" of household group (34\%) aged 30-39 or young adults in a household (37.8\%) aged 20-29. In fact, comparing Hong Kong returnees to Hong Kong-born stayers in Canada reveals more heads of households (33.5\% vs. $28.3 \%)$ and fewer spouses (17.2\% vs. $23.5 \%)$ in the returnee group. This may indicate that Hong Kong returnees from Canada may more likely be heads of the household who perhaps left their spouse and/or children in Canada. ${ }^{\text {xxi }}$

Table 4 also reveals that Canadian returnees to Hong Kong have a high degree of post-secondary education (50\%) and lead all other returning groups to Hong Kong, except those émigrés from the United States who report a 53\% rate. Hong Kong stayers in Canada have a much lower level of reported educational attainment, with only $25 \%$ reporting a post-secondary education: Chinese-Canadian émigrés to Hong Kong are positively sorted in terms of education.

A comparison of the occupational distributions of Canadian émigrés to Hong-Kong reveals minor negative sorting. In fact, returnees to Hong Kong are heavily concentrated in entry-level professional positions (34\%) with higher level professional or managerial jobs constituting $40 \%$ of the returnees. The corresponding stayer groups in Canada report 27\% of work in entry-level professional occupations and $46 \%$ in the managerial and professional grouping.

The human capital characteristics coupled with the occupational distributions of the émigrés discussed above will ultimately affect the returnee groups' earning levels. Those who returned to Hong Kong from the United States earned more than all other groups, with Canadian returnees earning the least among all returnee groups. In other words, returnees from Canada to Hong Kong earn about 30\% less than those returnees from the United States. However, Canadian returnees earn much more than Hong Kong-born stayers in Canada. Once more, this supports the sorting argument inherent in the triangular model. In fact, as shown in Table 4 the mean monthly earnings of Canadian returnees to Hong Kong is 2.3 times greater than that earned by Hong Kong stayers in Canada circa 2000. ${ }^{\text {xxii }}$

\section{Conclusions}

In sum, Canadian returnees to both of Canada's major émigré destinations, the United States and Hong Kong, have used Canada as an entrepôt destination and accumulated general capital (language, cultural understanding) and public goods (public education and citizenship) to exploit in another destination. Thus, these two groups show strong evidence of positive sorting; in turn this supports the choices of movement depicted in the triangular model. Whether this state of 
affairs requires intervention is not clear. First, the great majority of Canadian immigrants have not left Canada. Next, both Canadian-born and naturalized citizens form the majority of this exodus; there has been a limited policy response to this traditional 'brain drain issue' in the $21^{\text {st }}$ century since it is viewed by Canadians as part of a more benign 'brain circulation' issue. One major externality derived from a combination of citizenship acquisition and emigration is, however, cause for concern: the prospect of "checking out anytime you like, but never leaving", i.e., émigrés returning to Canada upon retirement to draw large social benefits to which they have not contributed.

\footnotetext{
i See Bo (2005) for a theoretically derived set of conditions to move and stay or leave country B with or without citizenship acquisition.

ii The ROW is characterized by no public goods provision to immigrants as well as a non-progressive income tax structure, thus attracting risktaking immigrants who shun public services and desire untaxed income.

iii Two factors affect the educational state of the potential mover. First, the educational conditions in the sending region relative to the conditions in the receiving country will influence the choice to stay or move for education (see Zhang and DeVoretz, 2002).

${ }^{\text {iv }}$ I omit the obvious possibility of moving from country A to country C (USA/R.O.W.) for education or employment for two reasons. First, we want to focus on the role of agents influencing the decision to move or to stay; by definition the USA has no agents. Second, the literature on the A-C movement is already extensive (Coulson and DeVoretz, 1992).

${ }^{\mathrm{v}}$ If students chose the United States or the ROW to study, then a second schematic would be needed. I recognize this possibility in Figure 1 and have modeled same with Zhang (DeVoretz and Zhang 2002) and refer readers to that exposition.

${ }^{\text {vi } H o w e v e r, ~ i n ~ e n t r e p o ̂ t ~ c o u n t r i e s ~ s u c h ~ a s ~ A u s t r a l i a, ~ C a n a d a, ~ G e r m a n y, ~ a n d ~ e s p e c i a l l y ~ I s r a e l, ~ g o v e r n m e n t ~ s u b s i d i e s ~ t o ~ p r i v a t e ~ a l t r u i s t i c ~ a g e n c i e s ~ i s ~}$ predicated on increasing the staying probability of the recent arrival and to increase the immigrant's contribution to the society. To this extent this governmental motive is not altruistic.

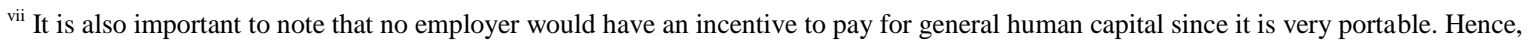
migrants would be forced to pay for this type of education if the state did not subsidize or completely provide it.

${ }^{\text {viii }}$ DeVoretz and Iturralde (2000b) offer evidence of the very high rewards attached to subsidized education in an entrepôt country (Canada) for migrants who left to work in the United States. For example, the return of return on the education of a Canadian with a Canadian Bachelor of Arts who worked in Canada circa 1996 was 12\% (pre-tax) as opposed to $44 \%$ for a migrant who moved to work in the United States.

${ }^{\mathrm{ix}}$ Note that entering the United States is excluded since one needs a passport issued by the host country according to this model.

${ }^{\mathrm{x}}$ Canada allows an application for citizenship in the first four years if three of the past four years were spent in residence in Canada [http://laws.justice.gc.ca/C-29/31864.html]. Other entrepôt countries such as Australia, Germany, and New Zealand have introduced minimum waiting periods before ascension to citizenship.

${ }^{x i}$ Access to the United States is limited to only those immigrants in country B who ascend to citizenship.

${ }^{x i i}$ Many countries (Germany, Netherlands, United States, etc.) either deny or discourage dual citizenships. This places an implicitly high tax on ascending to citizenship in the entrepôt countries.

${ }^{\text {xiii }}$ Also, immigrants ascending to citizenship in one member country of the European Union receive similar mobility rights in all member countries of the Union.

${ }^{\text {xiv }}$ The public good aspect of citizenship in country B arises from the good behavior of country A's past citizen-travelers.

${ }^{x v}$ This will be true only if the acquisition of country B's passport significantly does not lower the transaction costs of the newly naturalized immigrant's potential move to the ROW. This would be the case of a British naturalized citizen in Canada since his/her British passport generally allows easy access to the ROW.

${ }^{\text {xvi }}$ Clearly this would be the case of any immigrant naturalized in an EU country who would in turn gain mobility rights in a subset of 24 other EU member states.

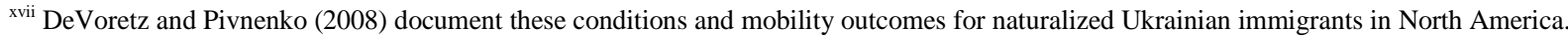


${ }^{\text {xviii }}$ A negative number indicates an inflow of immigrants from this country.

${ }^{\text {xix }}$ The increase I the number of Canadian citizens is no doubt due to the availability of NAFTA-derived TN visas which allowed Canadian citizens direct access to the United States: there was no numerical limit on these renewable one-year visas needed to work in over 66 occupations with only a bona fide job offer and relevant credentials required for valid admission. Of course other United States entry visas were available to highly skilled Canadians (H-1B, etc), but research has clearly shown that the TN visa dominated the inflow of Canadians during the 1990's and led to either long-term residency or conversion to a permanent residency status.

${ }^{\mathrm{xx}}$ Canadian-born residents in the United States are older and no doubt have completed their families; this would explain the large proportion of Canadian-born children in the United States.

${ }^{\mathrm{xxi}}$ Under our triangular model returnees would want their children to receive a subsidized high-quality Canadian education and their spouses must stay in Canada to insure this outcome.

${ }^{\text {xxii }}$ F. Tian and J. Ma (2008) reinforce these findings for Hong Kong with 2006 data. 